\title{
The prevalence of female sexual dissatisfaction and the dominant risk factors that may impair sexual satisfaction in Malaysian women
}

\author{
Hatta Sidi ${ }^{1}$, Sharifah Ezat Wan Puteh ${ }^{2}$, Norni Abdullah ${ }^{3}$, Marhani Midin ${ }^{1}$, Bastaman Basuki $^{4}$
}

\begin{abstract}
Abstrak
Pada tulisan disajikan hasil penelitian prevalens ketidakpuasan seksual dan beberapa faktor yang berkaitan di antara wanita pengunjung suatu rumah sakit di Malaysia selama periode Maret sampai Jun1 2005, dan menggunakan metode sampling nonprobabilitas. Untuk menilai ketidakpuasan seksual digunakan kuesioner yang telah divalidasi. Sejumlah 230 perempuan yang masih menikah berumur 21 - 62 tahun berpartispasi dalam penelitian ini. Keadaan sosiodemografi dan profile perkawinan diperbandingkan antara yang mengalami dan tidak mengalami ketidakpuasan seksual. Pada penelitian ini menunjukkan bahwa sebagian besar subjek berumur kurang dari 45 tahun, ras Melayu, dan berpendidikan tinggi. Sebanyak 52,2\% (120/230) mengalami ketidakpuasan seksual. Ras, penghasilan, pendidikan, masalah perkawinan, dismenorrhea, dan menacrhe kiranya tidak terbukti berkaitan dengan ketidakpuasan seksual. Pada penelitian ini terlihat bahwa faktor dominan yang berkaitan dengan ketidakpuasan seksual adalah umur suami. Sedangkan kekerapan hubungan kelamin secara moderat $(P=0,077)$ berkaitan dengan ketidakpuasan seksual. Subjek yang suaminya berusia 43-75 tahun dibandingkan dengan 24-42 tahun mempunyai risiko 68\% tebih tinggi mengalami ketidakpuasan seksual [risiko relatif suaian $(R R a)=1,68 ; 95 \%$ interval kepercayaan $(C I)=1,15-2,44]$. Jika ditinjau dari segi kekerapan hubungan kelamin per bulan subjek yang melakukan hubungan kelamin 1-3 kali per bulan dibandingkan dengan 4-5 kali per bulan mempunyai risiko dua kali lipat lebih tinggi untuk mengalami ketidakpuasan seksual ( $R R a=2,03 ; 95 \% C I=0,93-4,42 ; P=0,077)$. Dapat disimpulkan bahwa di antara subjek klinik di Malaysia ini prevalensi ketidakpuasan seksual dapat dikatakan tinggi, dan ketidakpuasan seksual ini sangat kuat berkaitan dengan subjek yang suaminya berusia tua. (Med J Indones 2007; 16:187-94)
\end{abstract}

\begin{abstract}
The study aims were to investigate the prevalence of sexual dissatisfaction and the potential risk factors. This was a cross-sectional study on women attending primary care setting in Malaysia over a period of March to June 2005, and used a non-probability sampling method. A validated questionnaire for sexual function was used. A total of 230 married women aged 21 - 62 years old participated in this study. The ressults show that the majority of the respondents were less than 45 years old, predominantly Malays, and with higher academic achievement. We noted that 52.2\% (120/230) study subjects had sexual dissatisfaction. Race, salary, education level, medical problems, dysmenorrhea, and menacrhe were likely not correlated with sexual dissatisfaction. The dominant risk factor related to sexual dissatisfaction was age of husband. In additional, sexual dissatisfaction was moderately $(P=0.077)$ related to sexual per month. The subjects who had their husbands aged 43-75 years compared with 24-42 years had 68\% increased risk to experience sexual dissatisfaction [adjusted relative risk $(R R a=1.68 ; 95 \%$ confidence interval $(C I)=1.15-2.44$ ]. In term of sexual frequency per month, those who had 1-3 times per month than 4-5 times per month had two-fold increased risk to experience sexual dissatisfaction $(R R a=2.03 ; 95 \% C I=0.93-4.42 ; p=0.077)$. In conclusion, the prevalence of sexual dissatisfaction was very high in Malaysian primary care population and it was strongly associated with women who married to an older husband and with infrequent sexual activity. (Med J Indones 2007; 16:187-94)
\end{abstract}

Keywords: sexual dissatisfaction, age of husbands, malaysian women

1 Department of Psychiatry, Faculty of Medicine, Universiti Kebangsaan Malaysia, Kuala Lumpur, Malaysia

2 Department of Community Health, Faculty of Medicine, Universiti Kebangsaan Malaysia, Kuala Lumpur, Malaysia

3 Department of Psychiatry, Hospital Tengku Ampuan Rahimah, Klang, Selangor, Malaysia

4 Department of Community Medicine, Faculty of Medicine, University of Indonesia, Jakarta, Indonesia
Sexual satisfaction, which is interchangeably expressed as sexual pleasure, has been accepted as a new important dimension in women sexuality. ${ }^{1}$ Sexual satisfaction is in fact a crucial determinant of a gratifying and meaningful sexual relationship as it improves intimacy ${ }^{2}$ and quality of life. ${ }^{3}$

The traditional model of normal sexual response cycle for women initially proposed by Masters and Johnson 
involves a linear genitally focused events of sexual desire, arousal and orgasm. ${ }^{3,4}$ Although this model has been widely accepted, this is more of an extrapolation from the male sexual response cycle and may not describe the actual experience of the women. Women may experience arousal, orgasm and satisfaction without starting with desire. ${ }^{3-5}$ They can also experience desire, arousal and satisfaction without having orgasm. ${ }^{2,3}$ Women's sexual experiences encompass self-esteem, body image, relationship factors, pleasure, satisfaction, and many other variables. ${ }^{2-7}$

A more current and widely acceptable alternative approach to the normative sexual experiences of women include the element of sexual satisfaction like one proposed by Sugrue and Whipple. ${ }^{3}$ This includes: capacity to experience sexual pleasure and satisfaction independent of the occurrence of orgasm; desire for, or receptivity to, sexual pleasure and satisfaction; physical capability to respond to stimulation (vasocongestion) without discomfort; and capability to experience orgasm under suitable circumstances. Sexual satisfaction and pleasure in women is also influenced by multiple factors including anatomical, physiological, medical, psychological and social. ${ }^{1-8}$ Cultural, contextual and religious factors also may play important role in sexual pleasure inhibitions. ${ }^{1,2,5,9,10}$

Sexual dysfunction in women as a whole was found to range from $25 \%$ to $63 \%$ in many countries. ${ }^{11,12}$ Sexual dissatisfaction was found in a global lifestyle study to range from $17.1 \%, 22.1 \%, 31.0 \%, 29.7 \%$ and $35.9 \%$ in Northern Europe, Southern Europe, Middle East, Far East Asia and South East Asia respectively. ${ }^{13}$ Sexual dissatisfaction and lack of sexual pleasure has been expressed by women and has been accepted as an important medical, interpersonal and marital issue in the west. ${ }^{4-6}$ In Malaysia, it is still a mystery. ${ }^{1}$ Among Malaysian women, the whole area of sexual problems tends to be regarded as trivial when compared to other health problems. ${ }^{1}$

In Malaysia, the whole area of women's sexuality is still largely uninvestigated. ${ }^{1}$ This is despite clear need for the area to be explored. Sexual problems among spouses have been reported to be the second leading cause for divorce between Muslim couples ${ }^{10}$ even though it is not clear whether this involves sexual dissatisfaction or other sexual problems. Furthermore, it is noted there have been increasing demands for clinical service for the problems among men and women. ${ }^{1,14}$ It is felt that sexual dissatisfaction or lack of sexual pleasure affects Malaysian women as much as it does to women in other countries. To date, as far as the author's knowledge, there has been no study looking into the area in Malaysia. ${ }^{1}$ It is the purpose of this study to explore this area in further detail.

Objective of this research paper was to investigate the prevalence of sexual dissatisfaction and several dominant risk factors that may impair sexual satisfaction among women in the Malaysian primary care population.

\section{METHODS}

This was a cross-sectional descriptive study on women attending the particular primary health clinic. It was conducted over a period of four months (March to June 2005). It was conducted at one of the government primary health care clinics located in Bandar Tun Razak, a rather busy suburban area of Kuala Lumpur, Malaysia. This primary health care clinic operates five days a week from Monday to Friday and offers nonemergency follow-up care for those with existing medical illness/illnesses and serves as a walk-in clinic for those without existing medical illness. It receives walk-in patients who live around the community area and those referred from the nearby hospitals and private practitioners. This clinic provides free services to the government servants, school students, children below one year old, adults aged 55 years and above and retired government servants.

This study used a non-probability sampling (universal sampling) method. Inclusion criteria include: (i) female patients; (ii) aged between 18 and 70 years old; (iii) married and have a sexually active partner; (iv) ability to read and understand the study languages (Malay or English); (v) consent for participation in the study. Exclusion criteria include: (i) chronic and severe medical illness/illnesses; (ii) psychiatric illness/illnesses; (iii) pregnancy; (iv) postpartum period of 2 months; (v) inability to read and understand the study languages; (vi) consent refusal to participate in this study.

The instruments used in this study were: (1) Sociodemographic and Marital Profile Form; (2) The Malay Version of Female Sexual Function Index (MVFSFI) ${ }^{15}$ (3) The Mini International Neuropsychiatric Interview (M.I.N.I.). ${ }^{16}$

\section{Sociodemographic and Marital Profile Form}

This is a brief questionnaire was devised to obtain respondents' sociodemographic and marital information. 
It includes name, age, educational level, employment status, monthly family income, medical history, menstrual history, duration of marriage, age of husband, number of children and frequency of sexual.

\section{Malay Version of Female Sexual Function Index (MVFSFI)}

Sexual dissatisfaction is measured in this study using the sexual satisfaction domain of the Malay Version of Female Sexual Functioning Index (MVFSFI). ${ }^{15}$ The original Female Sexual Function Index (FSFI) was developed by Dr. Raymond Rosen. It is a 19-item, multidimensional self-report measure of female sexual functioning. It covers 6 basic domains of female sexual functioning: desire, arousal, lubrication, orgasm, satisfaction, and pain. ${ }^{17}$

The MVFSFI ${ }^{15}$ was being validated by authors as part of the current study and for sexual satisfaction domain (as well as for other domains) it was found to have discriminate reliability between women with and without sexual dissatisfaction. The cut-off score for sexual satisfaction domain was established at $\leq 11$ (sensitivity $83 \%$ and specificity $85 \%$ ). The sexual satisfaction domain is measured by 4 questions (items 13 to 16 from the original questionnaire) asking about how satisfied the respondents were over the past 4 weeks with: their ability to reach orgasm during sexual; the amount of emotional closeness during sexual activity with their partners; their sexual relationship with their partners; and their overall sexual life. For each question, respondents may rate 0 (no sexual activity), 1 (very dissatisfied), 2 (moderately dissatisfied), 3 (about equally satisfied and dissatisfied), 4 (moderately satisfied) and 5 (very satisfied). These give a minimum score was 0 and maximum scores of 20 . The scores of 11 and below constitute sexual dissatisfaction or sexual dysfunction in satisfaction domain.

\section{Mini International Neuropsychiatric Interview (M.I.N.I.)}

The M.I.N.I. ${ }^{16}$ was used to exclude any respondents with psychiatric illness from this study. This is a brief structured interview for major Axis I psychiatric disorders in DSM-IV and ICD-10. It has been administered by one of the authors who was trained to use the instrument. It has been used in local studies and found to have good inter-rater reliability. The inter-rater reliability for this study was ascertained by administering the instrument on 10 cases selected randomly. This was done by two of the authors and yielded a kappa value of 1 .

Approval was obtained to conduct the study from the university ethical committee as well as from the administration authority of the particular clinic. All respondents who fulfilled the inclusion criteria were given an explanation about the study. A written consent was obtained from them. They were assured with regards to their anonymity and the confidentiality of the data obtained. A coding system was used to identify the respondents if it was necessary. The socio-demographic form and the MVFSFI were given to each respondent to be filled up in a room with some privacy. After the MVFSFI was completed, each respondent was engaged in a clinical interview for diagnosing sexual dysfunction based on the DSM-IV criteria $^{18}$ and administered the M.I.N.I for exclusion of the other psychiatric illnesses. Those who were found to have sexual dysfunction were referred to a sexologist for further management.

Analysis of the data to identify the risk factors related to female sexual dissatisfaction was done using Cox regression analysis with constant time. ${ }^{19}$ A risk factor was considered to be a potential confounder if in the univariate test the $P$-value $<0.25$ and would be considered as a candidate for the multivariate model along with all known risk factors for female sexual dissatisfaction. ${ }^{9}$ Ninety-five percent confidence intervals were based on the standard error of coefficient estimates. Statistical analyses were done using STATA 6.0 software.

\section{RESULTS}

Two hundred and forty eight (248) patients who attended the primary care clinic were invited to participate in the study. However, 18 patients were unable to complete the study because of multiple reasons such as unable to make time (4 patients), did not feel comfortable with the questions (7 patients) and did not bring their reading glasses to clinic (5 patients). The response rate was $93 \%$ with total subjects of 230. Two patients were screened and diagnosed to have anxiety disorder and major depressive disorder respectively by M.I.N.I. ${ }^{16}$ were excluded.

The studied urban women population was relatively of younger age [mean of 39.2 years, standard of deviation $(\mathrm{SD})=10.5$ ], slightly younger than their spouses (mean of 42.7 years, $\mathrm{sd}=11.3$ ) They had relatively high level of educational background (almost all had 
received at least primary level of education and still a majority had received at least secondary education). The Malays predominated other races $(76.1 \%)$ as compared with Chinese (13.9\%) and Indians (8.7\%). This is quite representative as the whole population of the area. Most of them come from the lower middle socioeconomic status, judging from their income levels. This is explained by the fact the richer ones would expectedly visit the private practitioners who offer a more flexible visiting times.

The mean duration of marriage among these women was $15.5(\mathrm{SD}=11.3)$. More than half of them $(66.7 \%)$ were from the pre-menopausal group. Majority of them $(43.5 \%)$ had between 2 to 5 children, $40 \%$ had less than 2 and $16 \%$ had more than 5 children. Only $10 \%$ of the women had sexual less than one time/month; $32.2 \%$ of them had it 1-2 times/month; a majority of them (44.3\%) had it 1-2 times/week; and $13.5 \%$ had it more than 2 times/month.
We noted that $52.2 \%(120 / 230)$ study subjects had sexual intercourse dissatisfaction. Race, salary, education level, medical problems, dysmenorrhea, and menacrhe were likely not correlated with sexual intercourse dissatisfaction. However, more women aged 46-62 years than 21-45 years, duration of marriage of 1-13 years than 14-42 years, number of children for 4-11 than $0-3$, had menopause than did not have menopause were more likely to experience sexual intercourse dissatisfaction (Table 1).

The final model (Table 2) shows that the dominant risk factor related to sexual dissatisfaction was age of husband. The subjects who had their husbands aged 43-75 years compared with 24-42 years had 68\% increased risk to experience sexual dissatisfaction. In term of sexual frequency per month, those who had 1-3 times per month than 4-5 times per month had two-fold increased risk to experience sexual dissatisfaction.

Table 1. Several factors and risk of sexual dissatisfaction

\begin{tabular}{|c|c|c|c|c|c|c|c|}
\hline & \multicolumn{4}{|c|}{ Dissatisfaction } & \multirow{3}{*}{$\begin{array}{l}\text { Crude } \\
\text { relative } \\
\text { risk }\end{array}$} & \multirow{3}{*}{$\begin{array}{l}95 \text { confidence } \\
\text { interval }\end{array}$} & \multirow{3}{*}{$\mathrm{P}$} \\
\hline & \multicolumn{2}{|c|}{$\begin{array}{c}\text { No } \\
(\mathrm{N}=110)\end{array}$} & \multicolumn{2}{|c|}{$\begin{array}{c}\text { Yes } \\
(\mathrm{N}=120)\end{array}$} & & & \\
\hline & $\mathrm{n}$ & $\%$ & $\mathrm{n}$ & $\%$ & & & \\
\hline \multicolumn{8}{|l|}{ Age group } \\
\hline $21-45$ years & 90 & 55.9 & 71 & 44.1 & 1.00 & Reference & \\
\hline $46-62$ years & 20 & 29.0 & 49 & 71.0 & 1.61 & $0.12-2.32$ & 0.010 \\
\hline \multicolumn{8}{|l|}{ Race } \\
\hline Malays & 85 & 48.6 & 90 & 51.4 & 1.00 & Reference & \\
\hline Non-Malays & 25 & 45.5 & 30 & 54.5 & 1.06 & $0.70-1.60$ & 0.780 \\
\hline \multicolumn{8}{|l|}{ Salary } \\
\hline RM 1,875-13,000 & 59 & 51.3 & 56 & 48.7 & 1.00 & Reference & \\
\hline RM 270-1,874 & 51 & 44.3 & 64 & 55.7 & 1.14 & $0.80-1.64$ & 0.466 \\
\hline \multicolumn{8}{|l|}{ Duration of marriage } \\
\hline $14-42$ years & 70 & 61.4 & 44 & 38.6 & 1.00 & Reference & \\
\hline $1-13$ years & 40 & 34.5 & 76 & 65.5 & 1.70 & $1.17-2.46$ & 0.005 \\
\hline \multicolumn{8}{|l|}{ Education } \\
\hline Higher academic & 88 & 50.3 & 87 & 49.7 & 1.00 & Reference & \\
\hline Lower academic & 22 & 40.0 & 33 & 60.0 & 1.21 & $0.81-1.80$ & 0.358 \\
\hline \multicolumn{8}{|l|}{ Number of children } \\
\hline $0-3$ & 79 & 56.0 & 62 & 44.0 & 1.00 & Reference & \\
\hline $4-11$ & 31 & 34.8 & 58 & 65.2 & 1.48 & $1.04-2.12$ & 0.031 \\
\hline \multicolumn{8}{|l|}{ Medical problem } \\
\hline Yes & 20 & 55.6 & 16 & 44.4 & 1.00 & Reference & \\
\hline No & 90 & 46.4 & 104 & 53.6 & 1.21 & $0.71-2.04$ & 0.485 \\
\hline \multicolumn{8}{|l|}{ Dysmenorrheal } \\
\hline Yes & 33 & 50.8 & 32 & 49.2 & 1.00 & Reference & \\
\hline No & 77 & 46.7 & 88 & 53.3 & 1.08 & $0.72-1.62$ & 0.388 \\
\hline \multicolumn{8}{|l|}{ Menarche } \\
\hline No & 32 & 51.6 & 30 & 48.4 & 1.00 & Reference & \\
\hline Yes & 78 & 46.4 & 90 & 53.6 & 1.11 & $0.73-1.67$ & 0.629 \\
\hline \multicolumn{8}{|l|}{ Menopause } \\
\hline No & 103 & 52.3 & 94 & 47.7 & 1.00 & Reference & \\
\hline Yes & 7 & 21.2 & 26 & 78.8 & 1.65 & $1.07-2.55$ & 0.024 \\
\hline
\end{tabular}


Table 2. Relationship between age of husband, number of sexual per month and risk of sexual dissatisfaction

\begin{tabular}{|c|c|c|c|c|c|c|c|}
\hline & \multicolumn{4}{|c|}{ Dissatisfaction } & \multirow{3}{*}{$\begin{array}{c}\text { Adjusted } \\
\text { relative } \\
\text { Risk* }^{*}\end{array}$} & \multirow{3}{*}{$\begin{array}{l}95 \text { confidence } \\
\text { interval }\end{array}$} & \multirow{3}{*}{$\mathrm{P}$} \\
\hline & \multicolumn{2}{|c|}{ No $(\mathrm{N}=110)$} & \multicolumn{2}{|c|}{ Yes $(\mathrm{N}=120)$} & & & \\
\hline & $\mathrm{n}$ & $\%$ & $\mathrm{n}$ & $\%$ & & & \\
\hline \multicolumn{8}{|l|}{ Age of husband } \\
\hline 21-42 years & 77 & 62.6 & 46 & 37.4 & 1.00 & Reference & \\
\hline 43-75 years & 33 & 30.8 & 74 & 69.2 & 1.68 & $1.15-2.44$ & 0.007 \\
\hline \multicolumn{8}{|l|}{ Sexual } \\
\hline 4-5 times per month & 24 & 77.4 & 7 & 22.6 & 1.00 & Reference & \\
\hline $1-3$ times per month & 86 & 43.2 & 113 & 56.8 & 2.03 & $0.93-4.42$ & 0.077 \\
\hline
\end{tabular}

* Adjusted each others for listed risk factors on this table

\section{DISCUSSION}

Sexual dissatisfaction or lack of pleasure and other sexual difficulties in women has largely been unexpressed in Malaysia and the topic only slowly appearing in the clinical context recently. ${ }^{1}$ Before, it was quite unheard of that women in this country would disclose this matter, therefore, making it hidden and neglected. ${ }^{1}$ This is despite the fact that sexual problems play a major role in causing marital disharmony and divorce.

Research involving women having to express their sexual activity and problems was thought to invite mixed feelings among the public. The more open minded and modernized ones would probably welcome the idea for academic or medical reasons, and others may regard it as vulgar and a form of pornography. ${ }^{1}$ As research in this area are scanty and at infantile stage in Malaysia, especially using a validated questionnaire, it is hoped that this piece of work would enlighten health care policy maker in future planning for sex education and providing sex counseling to couples and women with sexual difficulties.

This study examined the gravity of sexual dissatisfaction among women attending a primary care setting. There are two major findings from this study: the prevalence of sexual dissatisfaction among these women is unexpectedly high and this is found to be associated with several factors including older age, menopause, lesser duration of marriage and having more children. We also found that women married to an older husbands and having less frequent sexual were considered a dominant factors in predicting women's sexual dissatisfaction. Malaysian women, from this study, reported higher levels of lack of sexual satisfaction or pleasure if there were chances to disclose their discontentment, despite of societal, cultural, and religious values restriction. ${ }^{1}$ In fact, it can be concluded from this study that sexual dissatisfaction affects Malaysian women more than their counterparts in other countries. This is rather unexpected and alarming. It should be taken as a strong drive to mobilize health policy maker to provide help to our needy society. The need for change in the health service policy in favor to the facilitation of sexual health services being delivered to those affected is even greater as we also know that these women actually do not come forward to seek help. This was proven by the fact that these affected women in this study did not come to the health clinic to seek help for their sexual problems but rather for other health problems. It is also noted from the author's observation as one of the very few sexual health service providers in the country that the number of women coming forward to seek treatment is very low as compared to men. This phenomenon of women with sexual problems not seeking treatment is similar to that in other Asian countries, where nearly half of them do not seek treatment despite of having sexual difficulties. ${ }^{18}$

At a glimpse, it could be immediately seen that these dominant factors, such as getting married to an older husband and having infrequent sexual may be interacting with each other in the development of sexual dissatisfaction, even though, the causal relationship as to what is causing what cannot be established from this cross-sectional study. Sexual dissatisfaction has been reported in other studies to affect women being older age as well as from the post-menopausal. ${ }^{18,20}$ Logically, it could be that the older women are at risk of developing more medical/surgical problems and experience lack of vaginal lubrication. 
A woman's sexual satisfaction and pleasure may be affected by hormonal changes that occur as a result of normal female physiology such as menstrual cycle, postpartum states and lactation. ${ }^{4,21}$ It could also be due to fatigue and decrease well-being as well as lack of intimate relationship. ${ }^{2-4}$ These may occur more on older women and may be contributing to the higher prevalence of sexual dissatisfaction among them. Furthermore, physiological changes during primary menopause or changes that disrupt the natural progression of menopause such as surgically or medically induced menopause can result in inhibited sexual desire and satisfaction. ${ }^{7,20}$ Having less frequent thoughts about sex that occurs more in older women, having the belief that aging reduces sexual energy, depression and low expectations about the future of their relationships also may elevate the likelihood of reporting this problem. ${ }^{13}$

There could be other factors may be contributing to sexual dissatisfaction among women in this study. It was also found that women with sexual dissatisfaction were significantly having an older husbands. It may be related to the factors operating in their older husbands, for example, sexual difficulties related to medical problems that understandably occur more in the older men. ${ }^{6,7,20,21}$ This may affect the men's sexual performance and subsequently contribute to sexual dysfunction in women.

The women with sexual dissatisfaction in this study were also having significantly less sexual. This could also be a "chicken and egg" situation in terms of what is causing what. A woman who is not sexually satisfied or does not gain sexual pleasure may not want to engage in sexual activity frequently or the other way may also hold true that she is not satisfied sexually because of the infrequent sexual activity. It was also found that women with sexual dissatisfaction tend to have more children in this study. This could be due all the biopsychosocial aspects of increased parity that may affect their sexual functioning such as, hormonal changes, increase responsibility to take care of the increased number of family members, or due to lack of privacy for sexual encounters. It is a culture in Malaysia that small children sleep in the same bedroom with their parents up until they reach schooling age. ${ }^{1}$ It is also still a culture for an extended family to live under the same roof as well as it is still a culture that a retired woman takes care of her grandchildren while their children go to work. ${ }^{1}$ These may increase burden to the women as well as contribute to the lack of privacy for sexual encounters.
Interestingly, in our study, educational status, financial income, having medical problem and dysmenorrhea were not associated with sexual dissatisfaction as have been reported in other research studies. ${ }^{5-7}$ It may be possible that this is due to lack of heterogeneity in terms of educational status, financial income as the more educated and richer groups might not have attended to this free government clinic which only operate during limited hours and cater for large number of population. In the case of medical and mental health problems, serious medical and mental health problems such as chronic physical illnesses or psychiatric disorders have been excluded from the study in the first place as we are only interested on functional causes for sexual dissatisfaction. Other factors such as the presence of other forms of sexual problems, eg. difficulties in desire, arousal and orgasm as well as pain, which could also affect sexual satisfaction and pleasure. It was very likely that these also contributed to sexual dissatisfaction among the women in this study as majority of them also suffered from difficulties in more than one domain of sexual functioning.

There were several limitations of this research. First, the sample size is not large enough to obtain a definitive conclusion, but regression analysis was performed to examine the most predictable risk factors for sexual dissatisfaction. Married to an older husband and lesser sexual were found to be strong predictors for sexual dissatisfaction with the former was found to be the strongest predictor for sexual dysfunction in this study. We did not look into the male sexual function in our research (the sexual functioning of the husbands of the studied sample was not examined). Sexual satisfaction was found to be associated with male sexual dysfunction, especially erectile dysfunction. ${ }^{2,6,20}$ There is a possibility that these husbands have more medical problems due to age factors, suggesting that the women's sexual dysfunction is indirectly caused by their husband's performance. $^{6}$

Second, relationship issues, such as marital satisfaction between couples, were not investigated, because sexual satisfaction can actually reflect problems in intimacy and eroticism between couples. ${ }^{2}$

The other limitation is logistic set-up and readiness of our samples to participate in this study. Working in a government primary care clinic was not as easy as expected, and a study ${ }^{24}$ found many patients are reluctant to ask questions during evaluation, despite a 
high prevalence rate of lack of sexual satisfaction/ pleasure. For this reason, patients might be more comfortable answering questions presented on a standard questionnaire intake form. Stevenson $(2003)^{22}$ commented, this might be due to the perception or the actuality that the physician is too busy, or they are not approachable. Similarly, most health care providers fail to address sexual history as a part of the medical history. ${ }^{22}$

In term of setting, the clinic was always full of patients who came for the appointment and there were no proper place for the patients to fill up the questionnaire privately. Ideally each patient should fill up the questionnaires in a room with some privacy. However, at times they have to share the room with the other patients and this may affect the scoring of the questionnaire.

In term of respondents, this study only included the married women with sexually functioning partner. Those who were not married (single, divorce or widow) were excluded from this study because in Malaysia, most of the people in the society were unable to accept that the extramarital sexual relationship. However, there were many unmarried women sexually were active in Malaysia. Those who were not married but sexually active were approached during the pilot stage but they were reluctant to participate due to religious and cultural reasons.

Ideally, the author should conduct this study in community based and multiple centers, including the private general practitioner clinic, hence the heterogeneity of sampling will be better and the author could pick up more patients with sexual dysfunction.

This research as an important impact to our current understanding of magnitude of lack of sexual satisfaction/pleasure in our primary care population and treatment for lack of sexual pleasure is gradually evolving as more clinical and tailored towards the local needs. Psychological and intimacy based approach for sexual dysfunction are very crucial in sex therapy. ${ }^{1,2}$ Aside from hormone replacement therapy, medical management of female sexual dysfunction remains in experimental phases. ${ }^{20}$

With the improvements of medical attention, female sexual dysfunction has been recognized as an important element as in their male counterpart in terms of diagnosis ${ }^{4,520}$ and right for treatment in a more widely accepted, and as understood diseases. The importance of addressing issues of sexual dysfunction in women has emerged recently with more interest to do research in this area, including looking at the prevalence of sexual dysfunction using a validated questionnaire ${ }^{17}$ for health planning purpose and improvement of quality of life. ${ }^{4,20}$

The ideal approach to treat female sexual dysfunction is a collaborative effort between inter-disciplines including a complete medical, and psychosocial evaluation, as well as inclusion of the partner or spouse in the evaluation and treatment process. ${ }^{1-5,14,20}$

In conclusion, the prevalence of sexual dissatisfaction in Malaysian primary care women are alarming and needs to be addressed by medical and health authority, including primary care physician, counselors and other medical health specialists. Treatment options, despite of limited in resources in our local settings, should be explored, namely: psychological - counseling, education, and psychotherapy, and medical/physical healthy lifestyles, proper treatment for physical illness and probably hormonal/herbal treatment.

\section{Acknowledgement}

We would like to sincerely thanks the staff in Health Clinic, Bandar Tasik Selatan that had contributed to our research, such as collecting data and giving appointment to patients in the health clinic.

\section{REFERENCES}

1. Hatta S, Hatta SM, Ramli H. Seksualiti Manusia: Keharmonian Jalinan Antara Jantina. 2nd ed. Kuala Lumpur: Dewan Bahasa dan Pustaka; 2006.

2. Schnarch D. Passionate Marriage: Keeping Love \& Intimacy Alive in Committed Relationship. New York: Owl Books; 1997.

3. Sugrue DP, Whipple B. The consensus-based classification of female sexual dysfunction: barriers to universal acceptance. J Sex Mar Ther. 2001;7:221-6.

4. Basson R, Leiblum S, Brotto L, Derogatis L, Fourcroy J, Fugl-Meyer K. Revised definitions of women's sexual dysfunction. J Sex Med. 2004(1):40-8.

5. Basson R. Women's sexual dysfunction: revised and expanded definitions [review]. Can Med Assoc J. 2005;172:1327-33.

6. Laumann EO, Paik A, Anthony MA, Rosen RC. Sexual Dysfunction in the United States: Prevalence and Predictors. JAMA. 1999;281:537-44.

7. Basson R, Brotto LA, Laan E, Redmond G, Utian WH. Assessment and management of women's sexual dysfunctions: problematic desire and arousal. J Sex Med. 2005;2:291-300.

8. Basson R, Berman J, Burnet A, Derogatis L, Ferguson D, Fourcroy J, et al. Report of the International Consensus 
Development Conference on Female Sexual Dysfunction: Definitions and Classifications. J Urol. 2000;163:888-93.

9. Derobah JL. Female sexual Dysfunction. Mayo Clinic Proceeding. 2002;77:698-702.

10. Parlimentary discussion by Parlimentary Secretary in the Prime Minister's Department. Kuala Lumpur: Malaysia Today: The Independent News; April 25, 2005. [cited: 2006 May 27]. Available from: URL:http://www.malaysia-today.net/parlimen

11. Frank E, Anderson C, Rubinstein D. Frequency of sexual dysfunction in "normal" couples. New Engl J Med. 1978;299:111-5.

12. Spector IP, Carey MP. Incidence and prevalence of the sexual dysfunctions: a critical review of the empirical literature. Arch Sex Behav. 1990;19:389-408.

13. Laumann EO, Nicolosi A, Glasser DB, Paik A, Gingell C, Moreira E, Wang T, Group. ftGI. Sexual problems among women and men aged 40-80 years: prevalence and correlates identified in the Global Study of Sexual Attitudes and Behaviors. Int J Impot Res. 2004;17:39-57.

14. Basson R. Using a different model for female sexual response to address women's problematic low sexual desire. J Sex Mar Ther. 2001;27:395-403.

15. Sidi H, Puteh SEW, Midin M, Abdullah N. The prevalence of sexual pain disorder and potential risk factors that may associated with sexual pain in the Malaysian women. Mal J Obstet Gynaecol. 8;11:69-86.

16. Sheehan D, Janays J, Baker R, Harnett-Sheehan K, Knapp E, Sheehan M, Lecrubier Y, et al. The Mini International
Neuropsychiatric Interview (MINI): The development and validation of structured diagnostic psychiatric interview for DSM-IV and ICD-10. J Clin Psych. 1998; 59 Suppl 20:S22-3.

17. Rosen R, Brown C, Heiman J, Leiblum S, Meston CM, Shabsigh R, Ferguson D. The Female Sexual Function Index (FSFI): A multidimensional self-report instrument for the assessment of female sexual function. J Sex Marital Ther. 2000;26:191-208.

18. Nicolosi A, Dale B, Glasser SC, Kim KM, Laumann EO. Sexual behaviour and dysfunction and help-seeking patterns in adult age 40-80 years in the urban population of Asian countries. Br J Urol Int. 2005;95:609-14.

19. Barros AJD, Hirakata VN. Alternative for logistic regression in cross-sectional studies:an empirical comparison that directly estimates the prevalence ratio: BMC Medical Research Methadology [serial online]; Oct. 2003.

20. Lewis RW, Fugl-Meyer KS, Bosch R, Fugl-Meyer AR, Laumann EO, Lizza E, et al. Epidemiology/ risk factors of sexual dysfunction. J Sex Med. 2004; 1(1):35-9.

21. Bachmann G, Bancroft J, Braunstein G+-, et al. Female androgen insuffiecieny: the Princeton consensus statement on definition, classification and assessment. Fertil Steril. 2002;77:660-5.

22. Stevenson RWD. Sexual medicine: Why psychiatrist must talk to their patient about sex. Review paper. Can J Psych. 2004;49:673-7. 
